\title{
Article \\ Ferulago campestris Essential Oil as Active Ingredient in Chitosan Seed-Coating: Chemical Analyses, Allelopathic Effects, and Protective Activity against the Common Bean Pest Acanthoscelides obtectus
}

\author{
Roberta Ascrizzi ${ }^{1}\left(\mathbb{D}\right.$, Guido Flamini ${ }^{1}$ (D), Stefano Bedini ${ }^{2}$ (D), Camilla Tani ${ }^{2}$, Paolo Giannotti ${ }^{2}$, \\ Tiziana Lombardi ${ }^{2} \mathbb{D}$, Barbara Conti ${ }^{2,3, * \mathbb{D}}$ and Daniele Fraternale $\left.{ }^{4} \mathbb{(}\right)$
}

1 Department of Pharmacy, University of Pisa, Via Bonanno 6, 56126 Pisa, Italy; roberta.ascrizzi@gmail.com (R.A.); guido.flamini@unipi.it (G.F.)

2 Department of Agriculture, Food and Environment, University of Pisa, Via Del Borghetto 80, 56124 Pisa, Italy; stefano.bedini@unipi.it (S.B.); camilla.tani@phd.unipi.it (C.T.); paolo.giannotti@unipi.it (P.G.); tiziana.lombardi@unipi.it (T.L.)

3 CIRSEC, Centre for Climate Change Impact, University of Pisa, Via Del Borghetto 80, 56124 Pisa, Italy

4 Department of Biomolecular Sciences, Plant Biology Section, University of Urbino Carlo Bo, Via Bramante 28, 61029 Urbino, Italy; daniele.fraternale@uniurb.it

* Correspondence: barbara.conti@unipi.it

Citation: Ascrizzi, R.; Flamini, G.; Bedini, S.; Tani, C.; Giannotti, P.; Lombardi, T.; Conti, B.; Fraternale, D. Ferulago campestris Essential Oil as Active Ingredient in Chitosan Seed-Coating: Chemical Analyses, Allelopathic Effects, and Protective Activity against the Common Bean Pest Acanthoscelides obtectus.

Agronomy 2021, 11, 1578. https:// doi.org/10.3390/agronomy11081578

Academic Editor: Joseph M. Patt

Received: 8 July 2021

Accepted: 5 August 2021

Published: 9 August 2021

Publisher's Note: MDPI stays neutral with regard to jurisdictional claims in published maps and institutional affiliations.

Copyright: (c) 2021 by the authors. Licensee MDPI, Basel, Switzerland. This article is an open access article distributed under the terms and conditions of the Creative Commons Attribution (CC BY) license (https:// creativecommons.org/licenses/by/ $4.0 /)$.

\begin{abstract}
Ferulago campestris is an aromatic plant, distributed in Mediterranean Europe, and a source of essential oils (EOs) regarded as promising alternatives to synthetic herbicides and pesticides. F. campestris EO, hydrodistilled and analyzed, was tested for its antigerminative activity and for its effect on radicle elongation, hydrogen peroxide concentration, and lipid peroxidation on four infesting weed species (Papaver rhoeas, Taraxacum campylodes, Poa annua, and Setaria verticillata) and on Phaseolus vulgaris. Its repellent ability was also tested against Acanthoscelides obtectus, a pest commonly affecting P. vulgaris during storage. Moreover, a chitosan coating layer was developed with the addition of $F$. campestris $\mathrm{EO}$ and tested for its toxic and oviposition-deterring effects against A. obtectus. Myrcene, $\alpha$-pinene, and $\gamma$-terpinene were detected as the main compounds in $F$. campestris EO. The EO demonstrated a selective in vitro antigerminative activity towards the weed species, without affecting the bean seeds. Moreover, the chitosan coating layer exerted a dose-dependent repellent effect against $A$. obtectus adults, thus effectively protecting the bean seeds, while preserving their germinative ability. To the best of our knowledge, this is the first report on a chitosan-EO coating proposed with the aim of protecting bean seeds for sowing from insect attack.
\end{abstract}

Keywords: bean weevil; Phaseolus vulgaris; Papaver rhoeas; Poa annua; Taraxacum campylodes; Setaria verticillata

\section{Introduction}

Ferulago campestris (Besser) Grecescu (currently reported as a synonym of F. galbanifera W.D.J. Koch [1] and known in Italy as "Finocchiazzo") is a common herbaceous, spontaneous aromatic plant belonging to the Apiaceae family growing in Central Italy, but it also distributed in Southern Europe, from Southern France to Western Russia [2]. Its roots, aerial parts, and fruits are sources of essential oil (EO), whose chemical composition and biological activities have been studied by several authors; a hepato-protective effect, as well as activity on osteoblast metabolism, and antioxidant and antimicrobial properties have been reported for these EOs [3-7]. Recently, EOs of different Apiaceae species have also been studied concerning their possible application as natural insecticides or insect-repellents [8,9]. Regarding the Ferula genus, EOs from Ferula assa-foetida L. [10,11], Ferula galbaniflua [12], and Ferula hermonis Boiss [13] have been tested for their acarici- 
dal and insecticidal activity against Varroa destructor, Apis mellifera, Culex pipiens, and Blattella germanica.

Among insect pests, the bean weevil Acanthoscelides obtectus (Say) (Coleoptera Bruchidae) is a cosmopolitan insect pest that attacks various pulses and in particular the common bean Phaseolus vulgaris (L.) [14]. The attack occurs in the field and during storage [15]. In storehouses, this species is responsible for serious losses due to the larvae that penetrate the beans, eating their contents and reducing their weight [16]. Without any treatment, the $A$. obtectus populations grow exponentially and could completely destroy the stored beans [17]. The most common method to control weevil in beans for human consumption is by phosphine or pyrethroids [18]. As regards the seeds for sowing, the complete control of bruchids can be achieved by an insecticide coating of the stored seeds. The aim of the seed coating that contains an insecticide is to limit damage from insects both in storage facilities on the bean seeds and later, in the field, on the new crop. The widespread practice of using insecticides such as neonicotinoids for coating the seeds has however led to serious problems, such as those reported for years in the depopulation of bees [19]. In this scenario, there is a growing interest for alternative eco-friendly control substances to be used in coating seeds. Botanicals often fill these needs. In particular, in recent years, EOs of aromatic plants received great attention for pest control purposes due to their low toxicity to mammals and high biodegradability and the fact that they apparently do not induce resistance in target insects [9]. To produce an EO-based coating, one of the most promising natural substances is chitosan $(\mathrm{CH})$, a nontoxic, edible copolymer derived by deacetylation of chitin and consisting of $\beta$-(1,4)-2-acetamido-2-deoxy-d-glucopyranosyl and $\beta$-(1,4)-2-amino-2-deoxy-d-glucopyranosyl units [20].

Natural products, both as phytocomplexes and/or purified compounds, have also seen an increment in research interest for their phytotoxic activity against seeds of several weeds $[10,21-23]$ since the extensive use of synthetic herbicides has resulted in herbicideresistant weeds and intensive use of synthetic herbicides at high doses could generate toxic residues in agricultural products for humans and animals. It is known that natural compounds derived from plants as well as from essential oils and their components show a short half-life in the environment because they are easily biodegradable and thus produce little to no damage to the environment [24].

This study aimed at analyzing the composition of $F$. campestris fruit $\mathrm{EO}$ from specimens growing in the Marche region (Central Italy) and to test its effect on the germination of weeds and as insect repellent—alone or added with chitosan—against $A$. obtectus, which, to the best of our knowledge, has not yet been reported in the literature for this EO. Moreover, as several authors have reported that some EOs with antigermination activity have also induced oxidative stress on seeds and seedlings [22,24], another goal of our work was to verify whether the essential oil of $F$. campestris and its main compounds could induce oxidative stress in the germinating seeds employed in this study.

This research may be of interest not only by helping to understand some mechanisms of ecological interaction but also by helping to discover new substances or mixtures of substances possibly endowed with antigermination, herbicide, and insect-repellent activity for the formulation of natural products aimed at agricultural use, with minimal or no environmental impact that are also safer for human health.

\section{Materials and Methods}

\subsection{Plant Material and EO Hydrodistillation}

Ripe fruits of F. campestris were collected in August 2018 in Cesane Park, Urbino (Pesaro-Urbino PU), Central Italy, $600 \mathrm{~m}$ above sea level (N $\left.43^{\circ} 30^{\prime} 56^{\prime \prime} \mathrm{E} 12^{\circ} 49^{\prime} 13^{\prime \prime}\right)$. The plant was botanically determined by Prof. D. Fraternale. A voucher specimen was deposited in the Herbarium of the Botanical Garden of Urbino University Carlo Bo with the code FCS01. The essential oil was isolated from the fruits by hydrodistillation using a Clevenger-type apparatus for $3 \mathrm{~h}$, dried over anhydrous sodium sulfate, then stored in a 
sealed vial protected from the light at $-20{ }^{\circ} \mathrm{C}$ before the analysis and the use in biological tests [22]. The essential oil yield was $6.8 \% \mathrm{v} / \mathrm{dw}$ (mean of three replicates).

\subsection{Gas Chromatography-Mass Spectrometry Analyses and Peaks Identification}

The hydrodistilled EO was diluted to $0.5 \%$ in HPLC-grade $n$-hexane, then injected into a GC-MS apparatus. Gas chromatography-electron impact mass spectrometry (GC-EIMS) analysis was performed with an Agilent 7890B gas chromatograph (Agilent Technologies Inc., Santa Clara, CA, USA) equipped with an Agilent HP-5MS (Agilent Technologies Inc., Santa Clara, CA, USA) capillary column $(30 \mathrm{~m} \times 0.25 \mathrm{~mm}$; coating thickness $0.25 \mu \mathrm{m})$ and an Agilent 5977B single quadrupole mass detector (Agilent Technologies Inc., Santa Clara, CA, USA). Analytical conditions were set as reported in Ogunwande et al. [25]: injector and transfer line temperatures 220 and $240{ }^{\circ} \mathrm{C}$, respectively; oven temperature programmed from 60 to $240{ }^{\circ} \mathrm{C}$ at $3^{\circ} \mathrm{C} \mathrm{min}^{-1}$; carrier gas helium at $1 \mathrm{~mL} \mathrm{~min}^{-1}$; injection volume $1 \mu \mathrm{L}$ (0.5\% HPLC grade $n$-hexane solution); split ratio 1:25. Acquisition parameters were set as follows: full scan; scan range: $30-300 \mathrm{~m} / z$; scan time: $1.0 \mathrm{~s}$. The identification of constituents was based on a comparison of their retention times with those of authentic samples and comparing their linear retention indices relative to the series of $n$-hydrocarbons (C6-C25). Computer matching was also used against commercial libraries (National Institute of Standards and Technology 2014), a laboratory-developed mass spectra library (built up from pure substances and components of commercial essential oils of known composition), and MS literature data [26].

\subsection{Antigerminative Test}

The antigermination activity of F. campestris EO was tested following the method already used by Ricci et al. [22]. The following pure compounds, potentially responsible for the phytotoxic activity, present in the EO were tested: myrcene, $\alpha$-pinene, and $\gamma$ terpinene (all Sigma-Aldrich, Darmstadt, Germany). The three solutions were prepared so that each pure compound was present in the same percentage as that in the original F. campestris EO: $26.13 \%, 19.68 \%$, and $18.53 \%$, respectively, in $\mathrm{H}_{2} \mathrm{O} /$ Acetone $(99.5 / 0.5)$. A pure compounds mixture (PCM) was also prepared by mixing the three pure compounds in the same percentages present in the $\mathrm{EO}$ in $\mathrm{H}_{2} \mathrm{O}$ /acetone solution, as above. The PCM and each solution of the pure compound were used in the tests for seed germination at the same concentrations used for the original EO: 0.06, 0.125, 0.250, 0.625, and $1.250 \mu \mathrm{g} / \mathrm{mL}$. The seeds of $P$. rhoeas, T. campylodes, and P. vulgaris (var. "borlotto nano") were purchased from "Fratelli Ingegnoli" (Milan, Italy), while the seeds of $P$. annua and S. verticillata were collected from wild plants. Seed surfaces were cleaned in $95 \%$ ethanol for $15 \mathrm{~s}$, rinsed three times in distilled water, and sown in Petri dishes $(90 \mathrm{~mm} \varnothing)$ containing 5 layers of Whatman filter paper, soaked with $7 \mathrm{~mL}$ of either distilled water (control), the $\mathrm{EO}$, the PCM, or the solutions of the major pure components found in the EO. The acetone-water mixture behaves like water alone against the germination and radicle elongation of the seeds used as control. The culture conditions were $24 \pm 1{ }^{\circ} \mathrm{C}$, with a $16 \mathrm{~h}$ photoperiod of 1500 lux light. The herbicide Pendimethalin (36191, Supelco-Merck, Darmstadt, Germany) to a concentration of $0.06 \mu \mathrm{g} / \mathrm{mL}$ was also used as reference. Each Petri dish contained 10 seeds. A seed was considered germinated when the protrusion of the radicle became evident $(1 \mathrm{~mm})$. The number of germinated seeds and the length of the roots were recorded after five days. Data are expressed as the mean \pm SD of both germination and radicle elongation. Each experiment was performed in triplicate.

\subsection{Determination of Hydrogen Peroxide Concentration}

The concentrations of hydrogen peroxide in five-days-old roots were determined according to Ricci et al. [22] by measuring the titanium peroxide complex absorbance at $450 \mathrm{~nm}$. For preparing acidic titanium tetrachloride reagent, $10 \mathrm{~mL}$ portion of $6 \mathrm{~N}$ hydrochloric acid and a $10 \mathrm{~mL}$ portion of water-white titanium tetrachloride were cooled separately in beakers surrounded with crushed ice. The chilled titanium tetrachloride was 
added dropwise to the chilled acid solution. Foaming may occur if the acid solution is added to the titanium tetrachloride. The mixture was allowed to stand at ice temperature until the yellow solid dissolved and was then diluted to $1 \mathrm{~L}$ with hydrochloric acid $6 \mathrm{~N}$. Solutions prepared in this way contain about $4 \mathrm{mg}$ of Ti per $\mathrm{mL}$ and are stable. Then, $1 \mathrm{~g}$ of root material was extracted in $3 \mathrm{~mL}$ of ice-cold acetone, and $1 \mathrm{~mL}$ of extract was added to $0.1 \mathrm{~mL}$ of $20 \%$ titanium reagent and $0.2 \mathrm{~mL}$ ammonia solution with $17 \mathrm{~mol}$. After the centrifugation of this solution at $3000 \times \mathrm{g}$ at $4{ }^{\circ} \mathrm{C}$ for $10 \mathrm{~min}$, the supernatant was discarded, and the pellet was dissolved in $3 \mathrm{~mL}$ of sulfuric acid, with $1 \mathrm{~mol}$. The solution absorbance was measured at $410 \mathrm{~nm}$ with a "Carlo Erba reagents" spectrophotometer 6305. A standard curve, obtained with known concentrations of hydrogen peroxide, was used to calibrate the absorbance values read in the different conditions.

\subsection{Determination of Lipid Peroxidation}

The lipid peroxidation level in five-day-old roots was measured with the method indicated by Ricci et al. [22]. Briefly: $1 \mathrm{~g}$ of the roots grown under different conditions was homogenized in $3 \mathrm{~mL}$ of $0.1 \%$ TCA (trichloroacetic acid) and centrifuged at $15,000 \times g$ for $30 \mathrm{~min}$ at $4{ }^{\circ} \mathrm{C}$. An amount of $1 \mathrm{~mL}$ of the reagent obtained by mixing $0.5 \%$ thiobarbituric acid (TBA) in $20 \%$ TCA was added to $0.5 \mathrm{~mL}$ of previously obtained supernatants. The negative control was created by mixing $0.5 \mathrm{~mL}$ of $0.1 \%$ TCA and $1 \mathrm{~mL}$ of reagent, obtained as above. The test tubes were heated at $95^{\circ} \mathrm{C}$ for $30 \mathrm{~min}$ and then quickly cooled in an ice bath; after centrifugation, the supernatant absorbance was read at $532 \mathrm{~nm}$, and the value for the non-specific absorption at $600 \mathrm{~nm}$ was subtracted. The mmol/L extinction coefficient of $155 \mathrm{mmol} / 1 \mathrm{~cm}$ was used to assess the level of malondialdehyde (MDA).

\subsection{Insect Rearing}

A. obtectus strain was reared in the laboratory in an incubator at $27 \pm 1{ }^{\circ} \mathrm{C}, 60 \% \mathrm{RH}$ and in darkness in PVC boxes $(20 \times 25 \times 15 \mathrm{~cm})$ containing P. vulgaris var. "Borlotto" seeds. The boxes were covered by a nylon net allowing air exchange. Adults of homogeneous age were obtained by removing adults from each box daily, and the day after, newly emerged insects were used for the bioassay.

\subsection{Behavioral Assays}

The repellence/attractiveness of $F$. campestris $\mathrm{EO}$ towards $A$. obtectus females was evaluated in a two-choice olfactometer, a Plexiglas unit $(15 \times 15 \times 3 \mathrm{~cm})$, according to Romani et al. [27], with minor changes. In the center of the unit, a circular chamber (i.e., the specimen release chamber, diameter $4 \mathrm{~cm}$ ) was connected to two identical chambers by means of two linear paths (length, $2 \mathrm{~cm}$; width, $1 \mathrm{~cm}$ ), forming a $90^{\circ}$ angle. One of the two chambers contained a filter paper $(0.8 \mathrm{~mm} \varnothing)$ with $3 \mu \mathrm{L}$ of $n$-hexane as control, and the other chamber contained the same size filter paper with $3 \mu \mathrm{L}$ of the $5,10,15,17$, and $20 \%$ of $F$. campestris EO solution in $n$-hexane, corresponding to $14.4,28.9,43.3,49.1$, and $57.7 \mu \mathrm{L} / \mathrm{L}$ of air, respectively. The top of the arena was covered by a removable glass panel. In each trial, at the beginning of the test, a single individual was gently transferred into the release chamber on the floor of the chamber. Each A. obtectus female was observed for $6 \mathrm{~min}$. A choice was judged made if it moved from the central chamber within $20 \mathrm{~s}$ after being released and only when it stayed on the chosen source for at least $30 \mathrm{~s}$. For each A. obtectus female, the dwell time on a given cue was recorded. Individuals that did not make any choice were discarded. With each new specimen, the arena was rotated clockwise $90^{\circ}$ to avoid positional effects. Moreover, the relative position of the cues was randomized at each reply. For every bioassay, 30 females making the choice were considered. After each bioassay, the Plexiglas arena and the glass lid were first washed for about $30 \mathrm{~s}$ with hexane, then with warm water at $35-40^{\circ} \mathrm{C}$. The arena was then cleaned in a water bath with mild soap for about $5 \mathrm{~min}$, rinsed with hot water for about $30 \mathrm{~s}$, and finally rinsed with distilled water. Bioassays were conducted under laboratory conditions $\left(24^{\circ} \mathrm{C}\right.$ and $\left.65 \% \mathrm{RH}\right)$ [27]. 


\subsection{Chitosan and Chitosan-Essential Oil Coating}

Chitosan $(\mathrm{CH})$ was prepared following the protocol of Peng and Li [28], with small changes. In detail, chitosan from crab shells (CAS number: 9012-76-4) was completely dissolved in a deionized water solution of glacial acetic acid $(1 \% v / v)$ at a concentration of $2 \%(w / v)$, with a magnetic stirrer for $4 \mathrm{~h}$ at $25{ }^{\circ} \mathrm{C}$. To prepare the chitosan-essential oil solution (CH-EO), Tween 80 (final concentration $1 \%$ ) was added to the $2 \%$ chitosan solution above described. F. campestris EO was then added to the solution to obtain 10, 15, 20 , and $25 \%$ F. campestris EO solutions (corresponding to 100, 150, 200, and $250 \mathrm{~mL} / \mathrm{L}$ of EO) and mixed for 4 min with a magnetic stirrer.

P. vulgaris beans were coated with the $\mathrm{CH}$ and $\mathrm{CH}-\mathrm{EO}$ solutions at the different concentration $(10,15,20$, and $25 \%$ F. campestris $\mathrm{EO})$. The beans were immersed in the $\mathrm{CH}$ and $\mathrm{CH}-\mathrm{EO}$ solutions for $1 \mathrm{~min}$. The excess solution was drained off by keeping the beans over a wire rack positioned under the flow hood for $1 \mathrm{~h}$, and finally, the coated beans were air-dried for $24 \mathrm{~h}$ under laboratory conditions $\left(24^{\circ} \mathrm{C}\right.$ and $\left.65 \% \mathrm{RH}\right)$. The day after, the procedure was repeated a second time to obtain a double layer.

\subsection{Environmental Scanning Electronic Microscope Investigations and Measurements}

In order to determine the thickness of the double $\mathrm{CH}$ and $\mathrm{CH}-\mathrm{EO}$ coating layer, airdried coated beans were cut in half, mounted on stubs, and gold-coated in a sputter coater device (S150B; BOC Edwards, Burgess Hill, U.K.). Observations were made using an FEI Quanta 200 high-vacuum scanning electron microscope (Thermo Fisher Scientific, Inc., Waltham, MA, USA).

\subsection{Oviposition-Repellent Activity of $\mathrm{CH}-\mathrm{EO}$ of F. campestris}

A. obtectus adults were sexed after the emergence from beans, as described by Nahdy [29]. Couples (one female and one male) of newly emerged (0-24 h) adults were allow to mate in a Petri dish $(60 \mathrm{~mm} \times 15 \mathrm{~mm})$ for $24 \mathrm{~h}$ under laboratory conditions $\left(24{ }^{\circ} \mathrm{C}, 65 \% \mathrm{RH}\right.$ and in the dark). After the mating, a single female was placed in a Petri dish with one coated bean with $\mathrm{CH}$ or $\mathrm{CH}-\mathrm{EO}$ at the different concentrations $(10,15,20$, and $25 \%$ F. campestris EO). Uncoated beans were used as control (Control). Thirty replicates of each treatment were performed. After 14 days, the number of eggs laid, emerged larvae, and of larval entrance holes in the beans were recorded.

\subsection{Effects of F. campestris EO on Phaseolus Vulgaris Germination}

Seeds of $P$. vulgaris var. "Piattelli", uniform in size, were checked for their viability by suspending them in water and selecting those that remained on the bottom. The effects of the seeds coated with chitosan $(\mathrm{CH})$ and chitosan added with $25 \%$ EO of $F$. campestris coating (CH-EO 25\%) on plant growth were investigated by pot culture. The treated and untreated bean seeds were sown in pots $(30 \varnothing)$ containing $10 \mathrm{~L}$ of loam (Universal Toprak Virgoplant, Leroymerlin, Livorno, Italy). Ten beans were sown in each pot. The beans seedlings were grown for 14 days in a grow chamber at $25^{\circ} \mathrm{C}$ (day) and $23^{\circ} \mathrm{C}$ (night), with a 16:8 h L:D photoperiod (photosynthetically active radiation intensity $280 \mu \mathrm{E} \mathrm{s}^{-1} \mathrm{~m}^{-2}$ ) and $60 \pm 10 \%$ relative humidity. Afterwards root and shoot elongation were measured. The germination of the seeds was checked daily and the germination percentage (GP) was calculated according to Lombardi et al. [30] by the following formula:

$$
\mathrm{GP}=(\text { germinated seeds } / \text { total seeds tested }) \times 100
$$

P. vulgaris seedling root and hypocotyl elongation was measured at the end of the trial. Three replicates for treatment were performed.

\subsection{Data Analysis}

Data obtained from the behavioral assay were analyzed by likelihood chi-square test, with a null hypothesis of a 50:50 chance of insects choosing the control versus the EO- 
treated chamber. Data on the beans' protective effect of coating treatment were processed by Kruskal-Wallis test, with the number of eggs laid, the number of emerged larvae, and the number of holes bored in the beans as test variables and the coating treatment as grouping factor. Differences among plant germination and plant growth data of coated and non-coated beans were analyzed by one-way ANOVA with percentage germination, root length, and hypocotyl elongation as dependent variables and the coating treatment (Control, $\mathrm{CH}$, and $\mathrm{CH}-\mathrm{EO} 25 \%$ ) as factor. Percentage data (seeds germination) were arcsine transformed prior to statistical analysis. Homogeneity of variances was checked by a Levene's test before the analysis. Statistics were performed by SPSS 22.0 software (IBM SPSS Statistics, Armonk, North Castle, New York, NY, USA).

\section{Results and Discussion}

\subsection{Essential Oil Composition}

Forty-nine volatile components were identified in the EO obtained from F. campestris ripe fruits, corresponding to $99.4 \%$ of its total composition (Table 1).

Table 1. Complete composition of the essential oil hydrodistilled from ripe fruits of Ferulago campestris (Besser) Grecescu.

\begin{tabular}{|c|c|c|}
\hline Compounds & 1.r.i. ${ }^{a}$ & Relative Abundance (\%) \\
\hline tricyclene & 928 & $\operatorname{tr}^{b}$ \\
\hline$\alpha$-thujene & 931 & 1.1 \\
\hline$\alpha$-pinene & 941 & 19.7 \\
\hline$\alpha$-fenchene & 954 & $\operatorname{tr}$ \\
\hline camphene & 954 & 0.8 \\
\hline thuja-2,4(10)-diene & 959 & $\operatorname{tr}$ \\
\hline sabinene & 976 & 1.8 \\
\hline$\beta$-pinene & 982 & 2.8 \\
\hline myrcene & 993 & 26.1 \\
\hline$\alpha$-phellandrene & 1005 & 2.8 \\
\hline$\delta$-3-carene & 1011 & 5.9 \\
\hline$\alpha$-terpinene & 1018 & 0.7 \\
\hline p-cymene & 1027 & 2.6 \\
\hline limonene & 1032 & 6.6 \\
\hline$(Z)$ - $\beta$-ocimene & 1042 & 3.5 \\
\hline$(E)$ - $\beta$-ocimene & 1052 & 2.2 \\
\hline$\gamma$-terpinene & 1062 & 18.5 \\
\hline terpinolene & 1088 & 1.6 \\
\hline $1,3,8-p$-menthatriene & 1113 & $\operatorname{tr}$ \\
\hline 4-terpineol & 1178 & $\operatorname{tr}$ \\
\hline$\alpha$-terpineol & 1189 & $\operatorname{tr}$ \\
\hline trans-carveol & 1218 & $\operatorname{tr}$ \\
\hline citronellol & 1230 & $\operatorname{tr}$ \\
\hline cis-chrysanthenyl acetate & 1264 & 1.9 \\
\hline n-decanol & 1272 & $\operatorname{tr}$ \\
\hline bornyl acetate & 1287 & $\operatorname{tr}$ \\
\hline perilla alcohol & 1295 & $\operatorname{tr}$ \\
\hline trans-pinocarvyl acetate & 1297 & $\operatorname{tr}$ \\
\hline$\delta$-elemene & 1340 & 0.1 \\
\hline$\alpha$-copaene & 1376 & $\operatorname{tr}$ \\
\hline$\beta$-elemene & 1392 & $\operatorname{tr}$ \\
\hline$\beta$-caryophyllene & 1420 & 0.1 \\
\hline$\beta$-copaene & 1429 & $\operatorname{tr}$ \\
\hline$\alpha$-humulene & 1456 & $\operatorname{tr}$ \\
\hline germacrene D & 1478 & $\operatorname{tr}$ \\
\hline
\end{tabular}


Table 1. Cont.

\begin{tabular}{|c|c|c|}
\hline Compounds & 1.r.i. ${ }^{a}$ & Relative Abundance (\%) \\
\hline valencene & 1492 & 0.1 \\
\hline bicyclogermacrene & 1496 & $\operatorname{tr}$ \\
\hline$\alpha$-muurolene & 1498 & $\operatorname{tr}$ \\
\hline$\delta$-cadinene & 1524 & $\operatorname{tr}$ \\
\hline elemol & 1549 & $\operatorname{tr}$ \\
\hline germacrene B & 1554 & $\operatorname{tr}$ \\
\hline$(E)$-nerolidol & 1565 & $\operatorname{tr}$ \\
\hline spathulenol & 1576 & $\operatorname{tr}$ \\
\hline caryophyllene oxide & 1581 & $\operatorname{tr}$ \\
\hline humulene epoxide II & 1607 & $\operatorname{tr}$ \\
\hline neointermedeol & 1660 & $\operatorname{tr}$ \\
\hline nootkatone & 1803 & 0.1 \\
\hline$m$-camphorene & 1960 & 0.3 \\
\hline$p$-camphorene & 1995 & 0.1 \\
\hline \multicolumn{2}{|c|}{ Monoterpene hydrocarbons } & 96.6 \\
\hline \multicolumn{2}{|c|}{ Oxygenated monoterpenes } & 1.9 \\
\hline \multicolumn{2}{|c|}{ Sesquiterpene hydrocarbons } & 0.4 \\
\hline \multicolumn{2}{|c|}{ Oxygenated sesquiterpenes } & 0.1 \\
\hline \multicolumn{2}{|c|}{ Diterpene hydrocarbons } & 0.5 \\
\hline \multicolumn{2}{|c|}{ Non-terpene derivatives } & $\operatorname{tr}$ \\
\hline \multicolumn{2}{|c|}{ Total identified (\%): } & 99.4 \\
\hline
\end{tabular}

${ }^{\mathrm{a}}$ Linear retention indices on a HP-5MS capillary column; ${ }^{\mathrm{b}}$ Traces, $<0.1 \%$.

The major fraction was represented by monoterpene hydrocarbons (96.64\%), of which the most abundant were myrcene $(26.1 \%), \alpha$-pinene $(19.7 \%)$, and $\gamma$-terpinene $(18.5 \%)$, followed by limonene $(6.6 \%)$, and $\delta$-3-carene (5.9\%). Oxygenated monoterpenes $(1.9 \%)$, sesquiterpene hydrocarbons $(0.4 \%)$, oxygenated sesquiterpenes $(0.1 \%)$, diterpene hydrocarbons $(0.5 \%)$, and non-terpene derivatives $(\mathrm{tr},<0.1 \%)$ were all detected in relative concentrations below $2 \%$. The percentages of major compounds detected in the present study, such as myrcene, $\alpha$-pinene, and $\gamma$-terpinene, are in agreement with previous studies on the EO extracted from the fruits of F. campestris [6,7]. Moreover, monoterpene hydrocarbons constituted the main fraction of EOs obtained from both fruits and roots, with myrcene, $\alpha$-pinene, and $\gamma$-terpinene as the most abundant components of fruit EOs and $\alpha$-pinene as the predominant compound in root EO [4]. Monoterpene hydrocarbons also constituted the main fraction of $F$. campestris flower EO, with $\alpha$-pinene, myrcene, and $\gamma$-terpinene as the major components, while sesquiterpenes, especially the oxygenated ones, representing the most abundant chemical group in its leaf EO: $\alpha$-humulene, spathulenol, and caryophyllene oxide exhibited the highest relative abundances [3].

\subsection{Antigerminative Activity}

The hydrodistilled F. campestris EO was evaluated for its phytotoxic activity against germination and initial radicle elongation of red poppies (P. rhoeas), dandelions (T. campylodes), annual meadow-grass ( $P$. annua), hooked bristle grass ( $S$. verticillata), and common bean (P. vulgaris). The antigerminative activity of all the tested solutions on all the seeds is reported in Table 2. 
Table 2. Antigerminative activity-namely the ability of Ferulago campestris EO, pure compounds mixture (PCM), and main EO compounds to inhibit the germination of the seeds used in the experiment (Papaver rhoeas, Taraxacum campylodes, Poa annua, Setaria verticillata, and Phaseolus vulgaris seeds).

\begin{tabular}{|c|c|c|c|c|c|c|}
\hline \multirow[b]{2}{*}{ Plant } & \multirow[b]{2}{*}{ Sample/Conc. } & \multicolumn{5}{|c|}{ Number of Seeds Germinated of the 10 Used for Each Sample a } \\
\hline & & $0.06 \mu \mathrm{g} / \mathrm{mL}$ & $0.125 \mu \mathrm{g} / \mathrm{mL}$ & $0.250 \mu \mathrm{g} / \mathrm{mL}$ & $0.625 \mu \mathrm{g} / \mathrm{mL}$ & $1.250 \mu \mathrm{g} / \mathrm{mL}$ \\
\hline \multirow{7}{*}{ P. rhoeas } & $\mathrm{EO}$ & $10.0 \pm 0.0$ & $10.0 \pm 0.0$ & $10.0 \pm 0.0$ & $8.3 \pm 0.5$ & $7.6 \pm 0.5$ \\
\hline & PCM & $10.0 \pm 0.0$ & $10.0 \pm 0.0$ & $10.0 \pm 0.0$ & $9.5 \pm 0.4$ & $8.0 \pm 0.8$ \\
\hline & Myrcene/26.1\% & $10.0 \pm 0.0$ & $10.0 \pm 0.0$ & $10.0 \pm 0.0$ & $10.0 \pm 0.0$ & $8.0 \pm 1.4$ \\
\hline & $\alpha$-pinene $/ 19.7 \%$ & $10.0 \pm 0.0$ & $10.0 \pm 0.0$ & $10.0 \pm 0.0$ & $10.0 \pm 0.0$ & $8.3 \pm 1.7$ \\
\hline & $\gamma$-terpinene $/ 18.5 \%$ & $10.0 \pm 0.0$ & $10.0 \pm 0.0$ & $10.0 \pm 0.0$ & $10.0 \pm 0.0$ & $10.0 \pm 0.0$ \\
\hline & Pendimethalin & $0.0 \pm 0.0$ & & & & \\
\hline & Control $\left(\mathrm{H}_{2} \mathrm{O}\right)$ & $10.0 \pm 0.0$ & & & & \\
\hline \multirow{7}{*}{ T. campylodes } & EO & $10.0 \pm 0.0$ & $10.0 \pm 0.0$ & $10.0 \pm 0.0$ & $7.6 \pm 1.2$ & $8.6 \pm 1.2$ \\
\hline & PCM & $10.0 \pm 0.0$ & $10.0 \pm 0.0$ & $10.0 \pm 0.0$ & $8.6 \pm 0.4$ & $8.3 \pm 0.9$ \\
\hline & Myrcene/26.1\% & $10.0 \pm 0.0$ & $10.0 \pm 0.0$ & $10.0 \pm 0.0$ & $8.3 \pm 1.2$ & $8.0 \pm 1.4$ \\
\hline & $\alpha$-pinene $/ 19.7 \%$ & $10.0 \pm 0.0$ & $10.0 \pm 0.0$ & $10.0 \pm 0.0$ & $8.3 \pm 0.4$ & $8.6 \pm 1.2$ \\
\hline & $\gamma$-terpinene $/ 18.5 \%$ & $10.0 \pm 0.0$ & $10.0 \pm 0.0$ & $10.0 \pm 0.0$ & $10.0 \pm 0.0$ & $10.0 \pm 0.0$ \\
\hline & Pendimethalin & $0.0 \pm 0.0$ & & & & \\
\hline & Control $\left(\mathrm{H}_{2} \mathrm{O}\right)$ & $10.0 \pm 0.0$ & & & & \\
\hline \multirow{7}{*}{ P. апnиа } & EO & $10.0 \pm 0.0$ & $10.0 \pm 0.0$ & $10.0 \pm 0.0$ & $6.6 \pm 0.9 *$ & $6.0 \pm 0.8^{*}$ \\
\hline & PCM & $10.0 \pm 0.0$ & $10.0 \pm 0.0$ & $10.0 \pm 0.0$ & $7.3 \pm 0.4$ * & $6.3 \pm 0.4^{* *}$ \\
\hline & Myrcene/26.1\% & $10.0 \pm 0.0$ & $10.0 \pm 0.0$ & $10.0 \pm 0.0$ & $7.6 \pm 1.2$ & $7.3 \pm 0.4^{*}$ \\
\hline & $\alpha$-pinene $/ 19.7 \%$ & $10.0 \pm 0.0$ & $10.0 \pm 0.0$ & $10.0 \pm 0.0$ & $6.6 \pm 0.4 * *$ & $6.6 \pm 0.9 *$ \\
\hline & $\gamma$-terpinene $/ 18.5 \%$ & $10.0 \pm 0.0$ & $10.0 \pm 0.0$ & $10.0 \pm 0.0$ & $10.0 \pm 0.0$ & $10.0 \pm 0.0$ \\
\hline & Pendimethalin & $0.0 \pm 0.0$ & & & & \\
\hline & Control $\left(\mathrm{H}_{2} \mathrm{O}\right)$ & $10.0 \pm 0.0$ & & & & \\
\hline \multirow{7}{*}{ S. verticillata } & $\mathrm{EO}$ & $10.0 \pm 0.0$ & $10.0 \pm 0.0$ & $10.0 \pm 0.0$ & $6.6 \pm 0.4^{* *}$ & $5.6 \pm 0.4^{* *}$ \\
\hline & PCM & $10.0 \pm 0.0$ & $10.0 \pm 0.0$ & $10.0 \pm 0.0$ & $7.0 \pm 0.8^{*}$ & $6.6 \pm 0.4^{* *}$ \\
\hline & Myrcene/26.1\% & $10.0 \pm 0.0$ & $10.0 \pm 0.0$ & $10.0 \pm 0.0$ & $7.3 \pm 0.4^{*}$ & $7.0 \pm 0.8^{*}$ \\
\hline & $\alpha$-pinene $/ 19.7 \%$ & $10.0 \pm 0.0$ & $10.0 \pm 0.0$ & $10.0 \pm 0.0$ & $6.6 \pm 1.2$ & $6.3 \pm 1.2$ \\
\hline & $\gamma$-terpinene $/ 18.5 \%$ & $10.0 \pm 0.0$ & $10.0 \pm 0.0$ & $10.0 \pm 0.0$ & $10.0 \pm 0.0$ & $10.0 \pm 0.0$ \\
\hline & Pendimethalin & $0.0 \pm 0.0$ & & & & \\
\hline & Control $\left(\mathrm{H}_{2} \mathrm{O}\right)$ & $10.0 \pm 0.0$ & & & & \\
\hline \multirow{7}{*}{ P. vulgaris } & EO & $10.0 \pm 0.0$ & $10.0 \pm 0.0$ & $10.0 \pm 0.0$ & $10.0 \pm 0.0$ & $10.0 \pm 0.0$ \\
\hline & PCM & $10.0 \pm 0.0$ & $10.0 \pm 0.0$ & $10.0 \pm 0.0$ & $10.0 \pm 0.0$ & $10.0 \pm 0.0$ \\
\hline & Myrcene/26.1\% & $10.0 \pm 0.0$ & $10.0 \pm 0.0$ & $10.0 \pm 0.0$ & $10.0 \pm 0.0$ & $10.0 \pm 0.0$ \\
\hline & $\alpha$-pinene $/ 19.7 \%$ & $10.0 \pm 0.0$ & $10.0 \pm 0.0$ & $10.0 \pm 0.0$ & $10.0 \pm 0.0$ & $10.0 \pm 0.0$ \\
\hline & $\gamma$-terpinene $/ 18.5 \%$ & $10.0 \pm 0.0$ & $10.0 \pm 0.0$ & $10.0 \pm 0.0$ & $10.0 \pm 0.0$ & $10.0 \pm 0.0$ \\
\hline & Pendimethalin & $0.0 \pm 0.0$ & & & & \\
\hline & Control $\left(\mathrm{H}_{2} \mathrm{O}\right)$ & $10.0 \pm 0.0$ & & & & \\
\hline
\end{tabular}

a Seeds were considered germinated when the protrusion of the radicle became evident $(>1 \mathrm{~mm})$. Data are expressed as the mean \pm SD of seeds germinated. ${ }^{*}, p<0.05 ;{ }^{* *}, p<0.01$.

The EO showed a different effect on the germination and root development on the five tested seeds. At the concentration tested, seeds germination of P. annua and S. verticillata was inhibited by about $30 \%$ by the EO, the PCM, the myrcene solution $(26.1 \%)$, and the $\alpha$-pinene solution $(19.7 \%)$ at the concentrations of $0.625 \mu \mathrm{g} / \mathrm{mL}$ and $1.250 \mu \mathrm{g} / \mathrm{mL}(p<0.05$ and $p<0.01$ vs control). At these concentrations, the EO, the PCM, and the solutions of myrcene and $\alpha$-pinene alone showed the same inhibitory activity on the seeds of the two Poaceae species. The $\gamma$-terpinene solution (18.53\%) showed no inhibitory activity on the germination of the used seeds at any of the tested concentrations. Common bean seeds maintained the ability to germinate up to an EO concentration of $2.0 \mu \mathrm{g} / \mathrm{mL}$ (data not shown); higher EO concentrations were not tested in vitro for this species.

The activity of all the tested solutions on the radicle elongation of all the selected species is reported in Table 3. 
Table 3. Effect of Ferulago campestris EO, pure compounds mixture (PCM), and main EO compounds on Papaver rhoeas, Taraxacum campylodes, Poa annua, Setaria verticillata, and Phaseolus vulgaris radicle elongation.

\begin{tabular}{|c|c|c|c|c|c|c|}
\hline \multirow[b]{2}{*}{ Plant } & \multirow[b]{2}{*}{ Sample/Conc. } & \multirow[b]{2}{*}{$0.06 \mu \mathrm{g} / \mathrm{mL}$} & \multicolumn{4}{|c|}{ Radicle Elongation (cm) } \\
\hline & & & $0.125 \mu \mathrm{g} / \mathrm{mL}$ & $0.250 \mu \mathrm{g} / \mathrm{mL}$ & $0.625 \mu \mathrm{g} / \mathrm{mL}$ & $1.250 \mu \mathrm{g} / \mathrm{mL}$ \\
\hline \multirow{7}{*}{ P. rhoeas } & EO & $1.50 \pm 0.09$ & $1.46 \pm 0.10$ & $1.28 \pm 0.11^{* *}$ & $1.08 \pm 0.07^{* *}$ & $0.84 \pm 0.10$ ** \\
\hline & PCM & $1.52 \pm 0.07$ & $1.44 \pm 0.10$ & $1.32 \pm 0.07 *$ & $1.00 \pm 0.09^{* *}$ & $0.82 \pm 0.18$ \\
\hline & Myrcene/26.1\% & $1.54 \pm 0.05$ & $1.34 \pm 0.20$ & $1.24 \pm 0.10^{* *}$ & $0.96 \pm 0.08^{* *}$ & $0.80 \pm 0.06$ \\
\hline & $\alpha$-pinene $/ 19.7 \%$ & $1.48 \pm 0.07$ & $1.42 \pm 0.12$ & $1.12 \pm 0.11 *$ & $0.92 \pm 0.07^{* *}$ & $0.74 \pm 0.16$ \\
\hline & $\gamma$-terpinene $/ 18.5 \%$ & $1.58 \pm 0.04$ & $1.56 \pm 0.05$ & $1.54 \pm 0.05$ & $1.55 \pm 0.05$ & $1.56 \pm 0.04$ \\
\hline & Pendimethalin & $0.0 \pm 0.0$ & & & & \\
\hline & Control $\left(\mathrm{H}_{2} \mathrm{O}\right)$ & $1.61 \pm 0.20$ & & & & \\
\hline \multirow{7}{*}{ T. campylodes } & EO & $2.16 \pm 0.12$ & $2.02 \pm 0.13$ & $1.92 \pm 0.17^{* *}$ & $1.36 \pm 0.08^{* *}$ & $0.96 \pm 0.10^{* *}$ \\
\hline & PCM & $2.10 \pm 0.11$ & $1.98 \pm 0.04$ & $1.92 \pm 0.11 * *$ & $1.28 \pm 0.11^{* *}$ & $0.98 \pm 0.12^{* *}$ \\
\hline & Myrcene/26.1\% & $2.12 \pm 0.14$ & $1.94 \pm 0.07$ & $1.86 \pm 0.08^{* *}$ & $1.34 \pm 0.08^{* *}$ & $0.88 \pm 0.10^{* *}$ \\
\hline & $\alpha$-pinene $/ 19.7 \%$ & $2.06 \pm 0.08$ & $1.96 \pm 0.08$ & $1.92 \pm 0.07^{* *}$ & $1.26 \pm 0.10^{* *}$ & $0.90 \pm 0.11^{* *}$ \\
\hline & $\gamma$-terpinene $/ 18.5 \%$ & $2.42 \pm 0.07$ & $2.38 \pm 0.42$ & $2.42 \pm 0.07^{* *}$ & $2.36 \pm 0.05^{* *}$ & $2.30 \pm 0.06$ \\
\hline & Pendimethalin & $0.0 \pm 0.0$ & & & & \\
\hline & Control $\left(\mathrm{H}_{2} \mathrm{O}\right)$ & $2.48 \pm 0.21$ & & & & \\
\hline \multirow{7}{*}{ P. annua } & $\mathrm{EO}$ & $1.08 \pm 0.07$ & $0.94 \pm 0.08$ & $0.52 \pm 0.07^{* *}$ & $0.36 \pm 0.08^{* *}$ & $0.16 \pm 0.08^{* *}$ \\
\hline & PCM & $1.02 \pm 0.14$ & $0.82 \pm 0.16$ & $0.62 \pm 0.07^{* *}$ & $0.32 \pm 0.11^{* *}$ & $0.14 \pm 0.05^{* *}$ \\
\hline & Myrcene/26.1\% & $0.90 \pm 0.12$ & $0.86 \pm 0.05$ & $0.58 \pm 0.11^{* *}$ & $0.42 \pm 0.07^{* *}$ & $0.18 \pm 0.07^{* *}$ \\
\hline & $\alpha$-pinene $/ 19.7 \%$ & $1.06 \pm 0.13$ & $0.91 \pm 0.16$ & $0.58 \pm 0.07^{* *}$ & $0.36 \pm 0.10 *$ & $0.18 \pm 0.04^{* *}$ \\
\hline & $\gamma$-terpinene $/ 18.5 \%$ & $1.12 \pm 0.11$ & $0.96 \pm 0.08$ & $1.08 \pm 0.07$ & $1.00 \pm 0.06$ & $0.96 \pm 0.10 *$ \\
\hline & Pendimethalin & $0.0 \pm 0.0$ & & & & \\
\hline & Control $\left(\mathrm{H}_{2} \mathrm{O}\right)$ & $1.31 \pm 0.21$ & & & & \\
\hline \multirow{7}{*}{ S. verticilata } & $\mathrm{EO}$ & $1.42 \pm 0.15$ & $0.98 \pm 0.07^{* *}$ & $0.76 \pm 0.21 *$ & $0.34 \pm 0.10^{* *}$ & $0.13 \pm 0.04^{* *}$ \\
\hline & PCM & $1.42 \pm 0.14$ & $0.91 \pm 0.14 *$ & $0.71 \pm 0.27 *$ & $0.41 \pm 0.10^{* *}$ & $0.13 \pm 0.02 * *$ \\
\hline & Myrcene/26.1\% & $1.44 \pm 0.13$ & $0.94 \pm 0.08 *$ & $0.78 \pm 0.13^{* *}$ & $0.36 \pm 0.10^{* *}$ & $0.15 \pm 0.01 * *$ \\
\hline & $\alpha$-pinene $/ 19.7 \%$ & $1.46 \pm 0.13$ & $0.88 \pm 0.12 *$ & $0.76 \pm 0.18^{* *}$ & $0.32 \pm 0.13^{* *}$ & $0.12 \pm 0.01 * *$ \\
\hline & $\gamma$-terpinene $/ 18.5 \%$ & $1.54 \pm 0.08$ & $1.24 \pm 0.22$ & $1.28 \pm 0.21$ & $1.28 \pm 0.22$ & $1.52 \pm 0.30$ \\
\hline & Pendimethalin & $0.0 \pm 0.0$ & & & & \\
\hline & Control $\left(\mathrm{H}_{2} \mathrm{O}\right)$ & $1.60 \pm 0.31$ & & & & \\
\hline \multirow{7}{*}{ P. vulgaris } & EO & $2.04 \pm 0.10$ & $2.03 \pm 0.01$ & $2.16 \pm 0.12$ & $2.14 \pm 0.06$ & $2.14 \pm 0.04$ \\
\hline & PCM & $2.01 \pm 0.16$ & $2.07 \pm 0.07$ & $2.07 \pm 0.05$ & $2.05 \pm 0.07$ & $2.20 \pm 0.06$ \\
\hline & Myrcene/26.1\% & $2.06 \pm 0.08$ & $2.09 \pm 0.03$ & $2.05 \pm 0.05$ & $2.08 \pm 0.06$ & $2.16 \pm 0.04$ \\
\hline & $\alpha$-pinene $/ 19.7 \%$ & $2.02 \pm 0.14$ & $2.08 \pm 0.05$ & $2.05 \pm 0.06$ & $2.15 \pm 0.03$ & $2.06 \pm 0.03$ \\
\hline & $\gamma$-terpinene $/ 18.5 \%$ & $2.06 \pm 0.08$ & $2.10 \pm 0.05$ & $2.13 \pm 0.05$ & $2.12 \pm 0.06$ & $2.08 \pm 0.06$ \\
\hline & Pendimethalin & $0.00 \pm 0.00$ & & & & \\
\hline & Control $\left(\mathrm{H}_{2} \mathrm{O}\right)$ & $2.20 \pm 0.20$ & & & & \\
\hline
\end{tabular}

Interestingly, in the case of $S$. verticillata, $0.125 \mu \mathrm{g} / \mathrm{mL}$ of EO, PCM, myrcene solution, and $\alpha$-pinene solution induced inhibition of the root growth with respect to the control ( $p<0.05)$. In the case of P. rhoeas, T. officinale, and P. annua, the inhibition of root growth was detected at the concentration of $0.250 \mu \mathrm{g} / \mathrm{mL}$, while $0.650 \mu \mathrm{g} / \mathrm{mL}$ of EO, PCM, myrcene solution, and $\alpha$-pinene solution caused root browning and necrosis of the root tips in the germinating seeds of $P$. rhoeas, T. officinale, P. annua, and S. verticillata, which induced the arrest of the development of seedlings in vitro. The terpinene solution did not show this effect on emerging radicles at any of the tested concentrations.

The concentration of hydrogen peroxide and the lipid peroxidation level induced by all the tested solutions were evaluated in five-day-old roots of all species; results are reported in Table 4. 
Table 4. Hydrogen peroxide concentration and lipid peroxidation level in five-day-old roots of Papaver rhoeas, Taraxacum campylodes, Poa annua Setaria verticillata, and Phaseolus vulgaris.

\begin{tabular}{|c|c|c|c|c|c|}
\hline \multicolumn{6}{|c|}{$\mathrm{H}_{2} \mathrm{O}_{2}$ (ng/g FW) } \\
\hline & P. rhoeas & T. campylodes & P. annua & S. verticillata & P. vulgaris \\
\hline CTRL & $144.66 \pm 4.51$ & $155.66 \pm 7.51$ & $213.26 \pm 5.71$ & $209.90 \pm 7.32$ & $180.47 \pm 4.91$ \\
\hline FEO & $312.66 \pm 6.23 *$ & $451.00 \pm 6.16^{*}$ & $412.66 \pm 6.23$ * & $419.69 \pm 12.48 *$ & $182.33 \pm 5.24$ \\
\hline PCM & $314.33 \pm 6.94 *$ & $437.23 \pm 4.48 *$ & $416.66 \pm 3.85 *$ & $421.52 \pm 3.68 *$ & $181.84 \pm 1.89$ \\
\hline myrc. & $250.08 \pm 2.72 *$ & $283.06 \pm 6.09 *$ & $336.42 \pm 5.21 *$ & $317.55 \pm 5.13$ * & $183.42 \pm 4.25$ \\
\hline$\alpha$-pin. & $209.34 \pm 2.54$ * & $211.83 \pm 5.21 *$ & $229.36 \pm 4.15^{*}$ & $284.41 \pm 4.36^{*}$ & $179.81 \pm 4.12$ \\
\hline \multicolumn{6}{|c|}{ MDA (nmol/g FW) } \\
\hline CTRL & $39.95 \pm 2.03$ & $45.28 \pm 2.76$ & $46.90 \pm 1.96$ & $43.78 \pm 1.11$ & $32.04 \pm 0.12$ \\
\hline FEO & $73.26 \pm 1.42 *$ & $84.03 \pm 2.25 *$ & $85.44 \pm 2.28$ * & $80.07 \pm 2.11 *$ & $30.13 \pm 1.42$ \\
\hline PCM & $71.65 \pm 1.51 *$ & $81.99 \pm 1.19 *$ & $86.09 \pm 3.30 *$ & $81.53 \pm 0.64$ * & $31.01 \pm 1.45$ \\
\hline myrc. & $53.57 \pm 3.43 *$ & $74.31 \pm 4.25 *$ & $61.39 \pm 2.14 *$ & $65.13 \pm 2.27 *$ & $30.16 \pm 1.65$ \\
\hline$\alpha$-pin. & $52.28 \pm 2.11 *$ & $65.41 \pm 2.64 *$ & $63.67 \pm 2.38 *$ & $74.09 \pm 3.24 *$ & $32.49 \pm 1.66$ \\
\hline
\end{tabular}

Hydrogen peroxide $\left(\mathrm{H}_{2} \mathrm{O}_{2}\right)$ and malondialdehyde (MDA) content from the five-day-old rootlets of the weed seeds and the seeds of P. vulgaris germinating in control (CTRL), Ferulago campestris seeds essential oil (FEO), myrcene $26.1 \%$ plus $\alpha$-pinene $19.68 \%$ (PCM), myrc. (myrcene solution $26.13 \%$ alone), and $\alpha$-pin. ( $\alpha$-pinene solution $19.7 \%$ alone) at a $0.625 \mu \mathrm{g} / \mathrm{mL}$ concentration. ${ }^{*} p \leq 0.01 \mathrm{vs}$ control, according to Student's $t$ test.

The EO, the myrcene solution (26.1\%), the $\alpha$-pinene one (19.7\%), and the PCM induced at a concentration of $0.625 \mu \mathrm{g} / \mathrm{mL}$ a significant increase in the level of $\mathrm{H}_{2} \mathrm{O}_{2}$ in emerging weed roots of $P$. rhoeas, T. campylodes, P. annua, and S. verticillata compared with the control but not in the common bean, which showed no stress signals up to the highest tested EO concentration of $2.0 \mu \mathrm{g} / \mathrm{mL}$ (data not shown). The significant increase in the roots level of $\mathrm{H}_{2} \mathrm{O}_{2}$ further increases the lipid peroxidation in all the four weed roots tested five days after sowing. At the same time, with the increase of hydrogen peroxide caused by the EO and PCM, an increase in malondialdehyde (MDA) content was observed, and therefore an increase in the lipid peroxidation in the radicles of the weed seeds. MDA, indeed, represents a product of unsaturated fatty acid peroxidation in phospholipids, responsible for cell membrane damage and subsequent blackening and necrosis of the radicles.

The $\alpha$-pinene solution $(19.7 \%)$ was more active than the myrcene solution $(26.1 \%)$ in increasing the levels of $\mathrm{H}_{2} \mathrm{O}_{2}$ and MDA for all the tested weeds; however, in PCM, these two activities are enhanced, and this could depend on a synergistic effect between the two monoterpenes. It is known that monoterpenes have an important bioactivity in the allelopathic interactions between plants. Hsiung et al. [31] showed that myrcene inhibited the growth of rice seedlings, particularly root growth, and that the activity of ROS and lipoxygenases (LOX) was significantly increased with increasing myrcene concentration in the growth bioassay test. The activity of the antioxidant enzymes superoxide dismutase and peroxidase is also modified in a dose-dependent manner. Scrivanti et al. [32] showed an increase in malondialdehyde in maize roots treated with $\alpha$-pinene, the second most abundant EO in the present study. This monoterpene inhibited the radicle growth of Cassia occidentalis, Amaranthus viridis, Triticum aestivum, Pisum sativum, and Cicer arietinum, and the exposure of $C$. occidentalis root to this monoterpene enhanced solute leakage and increased the level of malondialdehyde, proline, and hydrogen peroxide, indicating lipid peroxidation and a condition of oxidative stress [33]. Furthermore, the activity of the antioxidant enzymes such as superoxide dismutase, catalase, glutathione peroxidase, and glutathione reductase were significantly elevated, indicating that the exposure to $\alpha$-pinene certainly induces an increase in the generation of reactive oxygen species. In our experiment, we saw that an EO concentration up to $2.0 \mu \mathrm{g} / \mathrm{mL}$ had no effect on the germinability and on the induction of oxidative stress on bean seeds; other authors [33] have shown that formulations containing $\alpha$-pinene (98\%) inhibited the germination of P. sativum and $C$. arietinum seeds but at concentrations much higher than the ones we tested (from 0.136 to $1.360 \mathrm{mg} / \mathrm{mL}$ ). Chowhan et al. [34] showed that $\alpha$-pinene and $\beta$-pinene reduce the chlorophyll content in Oryza sativa coleoptiles, with the cell respiration, the enzymatic 
activity of proteases, $\alpha$ - and $\beta$-amylases, and root and coleoptiles length increasing in a dose-dependent manner the activity of peroxidases and polyphenols oxidases as a defense mechanism. However, the phytotoxic properties of $\alpha$-pinene have been confirmed by several authors [35,36]. Amri et al. [37] reported that $\alpha$-pinene has a specific ecological role in the allelopathic activity between plants, so it could be considered for the development of natural herbicides. According to the results that emerged in the present study, the EO of the ripe fruits of F. campestris, which is a spontaneous and unexploited plant, might exert its phytotoxic activity due to its content of myrcene and $\alpha$-pinene.

\subsection{Behavioral Assays}

The tests performed by the two-choice olfactometer showed that F. campestris EO exerted a dose-dependent repellent effect against $A$. obtectus adults that increased together with the increment of the $\mathrm{EO}$ concentration (Figure 1). A significant repellence activity was reached at 49.1 and $57.7 \mu \mathrm{L}$ of $\mathrm{EO} / \mathrm{L}$ of $\operatorname{air}\left(\chi^{2}=10.800, p=0.001 ; \chi^{2}=22.533, p<0.001\right)$. No significant effect was observed at the lower concentrations of $14.4,28.9$, and $43.3 \mu \mathrm{L} / \mathrm{L}$ $\left(\chi^{2}=0.000, p=1.000 ; \chi^{2}=0.533, p=0.465 ; \chi^{2}=3.333, p=0.068\right.$, respectively $)$. The behavioral assays evidenced a significant repellent activity starting from the dose of $49.1 \mu \mathrm{L} / \mathrm{L}$ of air of F. campestris EO. The bioactivity was confirmed in in vitro bioassays, where the F. campestris $\mathrm{EO}$ at different doses was mixed with chitosan for producing a coating to protect the bean seeds against the attack of $A$. obtectus.

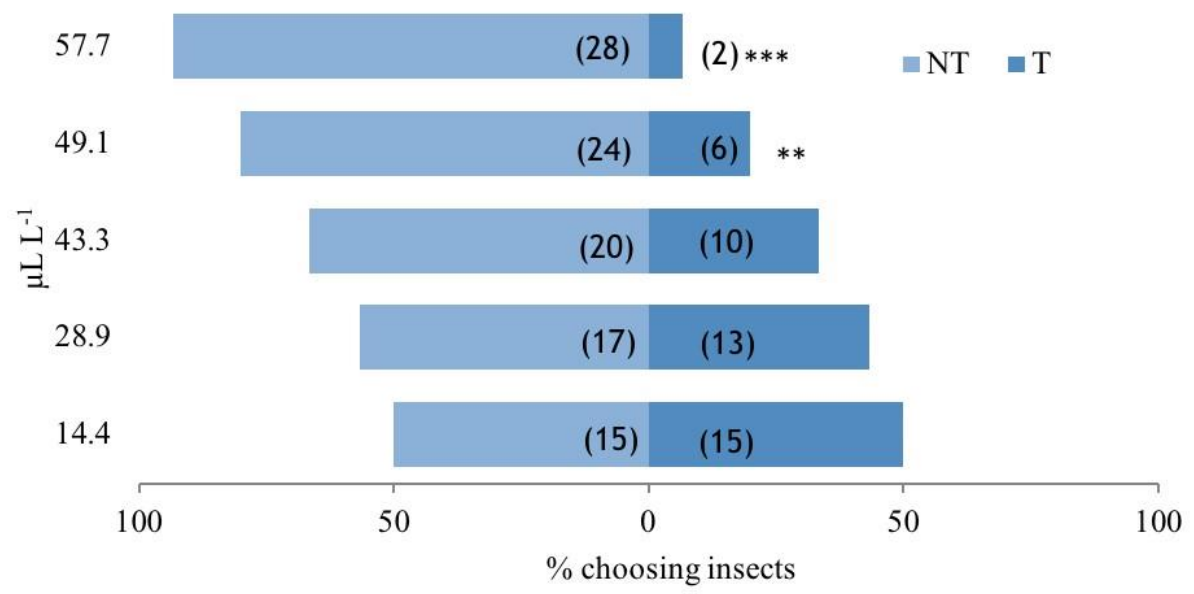

Figure 1. Behavior of Acanthoscelides obtectus females in the presence of Ferulago campestris essential oil. Histograms represent the percentage of insects that chose the cue or the control chamber. On the $y$ axis are reported the concentrations of the cue tested ( $\mu \mathrm{L}$ of $\mathrm{EO} \mathrm{L} \mathrm{L}^{-1}$ air). Numbers in brackets indicate the number of choosing insects; NT, percentage of insects that chose the control chamber; T, percentage of insects that chose the $\mathrm{EO}$ treated chamber. Asterisks indicate significant differences in the number of the choosing insects according to a $\chi^{2}$ test $\left(^{* *} p<0.01 ;{ }^{* *} p<0.001\right)$.

The repellency of F. campestris EO is confirmed by the study of Papachristos and Stamopoulos [38], where nine different EOs, among the thirteen tested, showed a strong repellent activity against $A$. obtectus females. In fact, the study of the distribution of the females showed that in the presence of Laurus nobilis, Rosmarinus officinalis, Eucalyptus globulus, Juniperus oxycedrus, Lavandula hybrida, Mentha microphylla, Mentha viridis, Origanum vulgare, and Apium graveolens EOs, the majority of females ( $>80 \%)$ moved towards the control after a few hours of exploration. Viteri Jumbo et al. [39] also observed a repellent activity against $A$. obtectus after the application of Cinnamomum zeylanicum EO at the doses of 46.8 and $122.4 \mu \mathrm{L} / \mathrm{kg}$ beans, very similar to the doses utilized in this experiment. The use of a polymer such as chitosan for the nanoencapsulation/nanoemulsion of EOs has already been investigated and tested against $A$. obtectus [40]. However, to the best of our 
knowledge, this is the first time that chitosan coating has been proposed with the addition of an $\mathrm{OE}$ with the aim of the protection of bean seeds for sowing in storage facilities.

\subsection{Environmental Scanning Electronic Microscope Investigations and Measurements}

The investigations conducted by an environmental scanning electronic microscope (ESEM) allowed us to define the thickness $(66.23 \mu \mathrm{m})$ of the double coating layer of $\mathrm{CH}-\mathrm{EO}$ of F. campestris utilized in the research for the protection of the bean seeds (Figure 2).

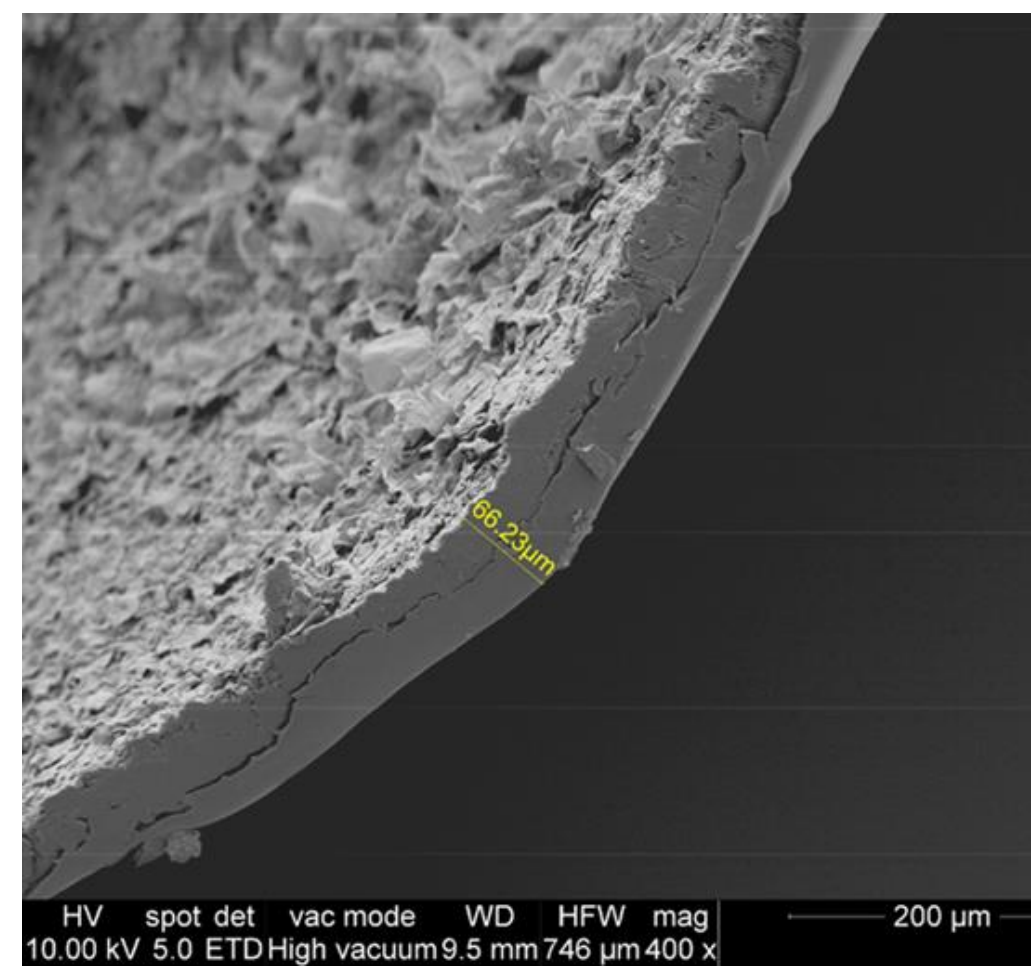

Figure 2. Environmental scanning electronic microscope (ESEM) picture showing the thickness (in yellow) of the double coating layer of chitosan added with Ferulago campestris essential oil utilized for the protection of the bean seeds.

\subsection{Chitosan Coating Protection Test of P. vulgaris Beans}

The performed tests evidenced a clear effectiveness of the $\mathrm{CH}-\mathrm{EO}$ coating in the protection of the beans against A. obtectus (Figure 3). Kruskal-Wallis tests showed a significant difference among coating treatments in the number of the eggs laid on the beans $\left(\chi^{2}=48.826 ; \mathrm{df}=5 ; p<0.001\right)$, number of emerged larvae $\left(\chi^{2}=49.736 ; \mathrm{df}=5 ; p<0.001\right)$, and number of larvae entrance holes in the beans $\left(\chi^{2}=59.723 ; \mathrm{df}=5 ; p<0.001\right)$.

The Dunn-Bonferroni pairwise comparisons between bean treatments indicated a significant difference between control and the $\mathrm{CH}-\mathrm{EO}$ treatments for the number of laid eggs (CH-EO $10 \%$ vs. control, $p=0.01 ; \mathrm{CH}-\mathrm{EO} 15 \%$ vs. control, $p<0.001 ; \mathrm{CH}-\mathrm{EO} 20 \%$ vs. control, $p<0.001 ; \mathrm{CH}-\mathrm{EO} 25 \%$ vs. control, $p=0.003)$, while the control and all the coating treatments were significantly different for number of emerged larvae $(\mathrm{CH}$ vs control, $p=0.025 ; \mathrm{CH}-\mathrm{EO} 10 \%$ vs. control, $p<0.001 ; \mathrm{CH}-\mathrm{EO} 15 \%$ vs. control, $p<0.001 ; \mathrm{CH}-\mathrm{EO}$ $20 \%$ vs. control, $p<0.001$; CH-EO $25 \%$ vs control, $p<0.001$ ) and for the number of bored entrance holes (CH vs. control, $p=0.049 ; \mathrm{CH}-\mathrm{EO} 10 \%$ vs. control, $p<0.001 ; \mathrm{CH}-\mathrm{EO} 15 \%$ vs. control, $p<0.001$; CH-EO $20 \%$ vs. control, $p<0.001$; CH-EO $25 \%$ vs. control, $p<0.001$ ). 


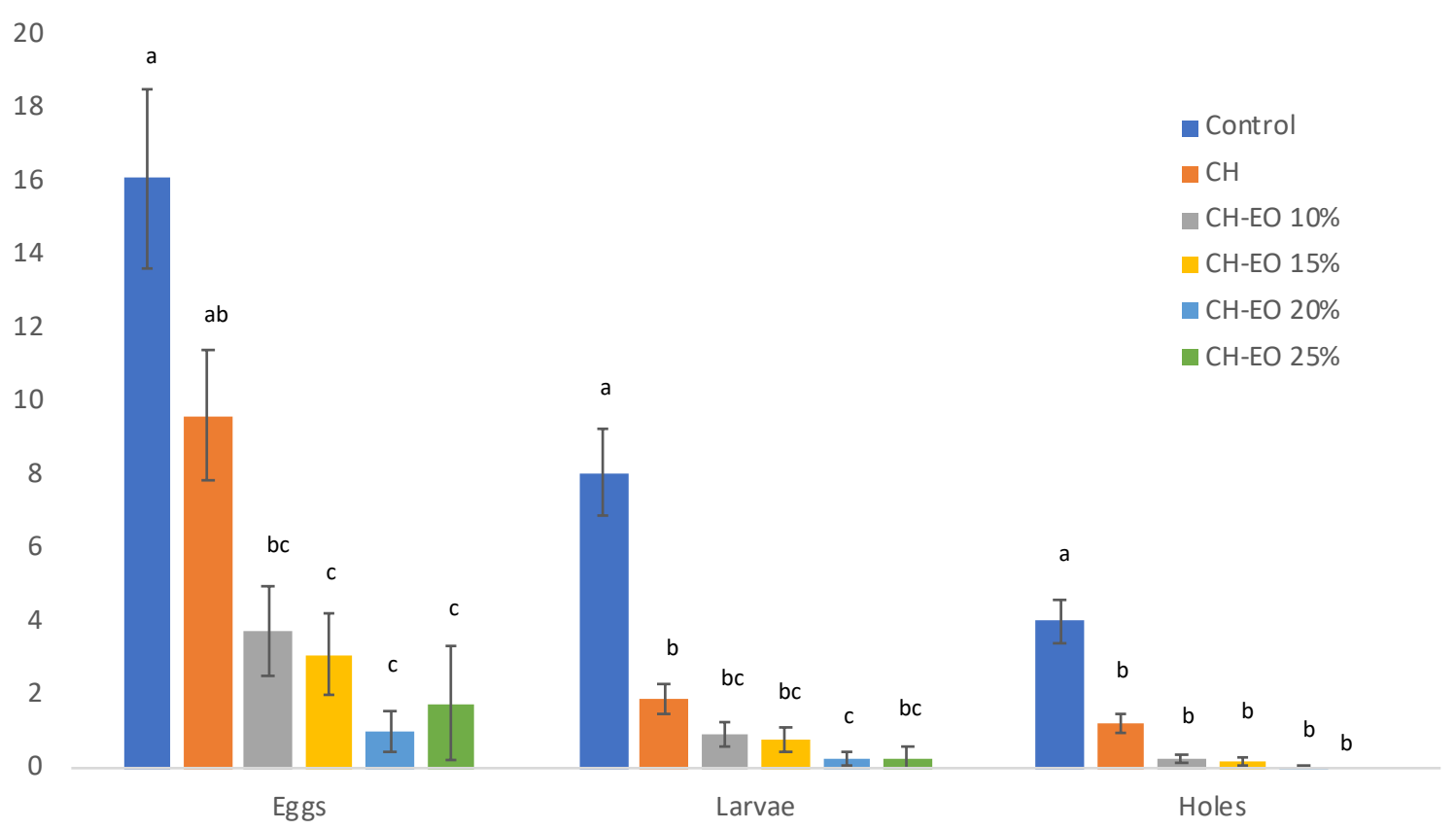

Figure 3. In vitro protective effect of chitosan and chitosan plus Ferulago campestris essential oil (EO) against reproductive activity of females of Acanthoscelides obtectus. Histograms ( $y$ axis) represent the mean values of eggs, larvae, and larval entrance holes. Bars represent standard error. Control, untreated beans; $\mathrm{CH}$, chitosan coated beans; $\mathrm{CH}-\mathrm{EO}$ beans coated with chitosan added with EO at different percentages; different letters indicate significant differences according to Dunn-Bonferroni pairwise comparisons test $(p \leq 0.05)$.

\subsection{Effects of Chitosan-F. campestris EO on P. vulgaris Germination}

The coating treatment of the beans with $\mathrm{CH}$ and $\mathrm{CH}-\mathrm{EO}$ of $F$. campestris did not affect the $P$. vulgaris germination $\left(F_{2,8}=0.250, p=0.787\right)$, or the seedling root and hypocotyl elongation $\left(F_{2,8}=0.141, p=0.871 ; F_{2,8}=3.133, p=0.117\right.$, respectively) (Table 5).

Table 5. Effects of $\mathrm{CH}$ and $\mathrm{CH}-\mathrm{EO}$ of Ferulago campestris coating on seeds germination and radicle and shoot elongation of Phaseolus vulgaris seedlings.

\begin{tabular}{|c|c|c|c|}
\hline & $\%$ Germination ${ }^{a}$ & Root Length $^{b}$ & $\begin{array}{l}\text { Hypocotyl } \\
\text { Elongation }\end{array}$ \\
\hline Control & $83.33 b \pm 12.02$ & $7.72 \pm 0.61$ & $9.40 \pm 0.47$ \\
\hline $\mathrm{CH}$ & $80.00 \pm 11.55$ & $7.25 \pm 0.92$ & $8.17 \pm 0.14$ \\
\hline CH-EO 25\% & $90.00 \pm 5.77$ & $7.70 \pm 0.49$ & $8.80 \pm 0.35$ \\
\hline
\end{tabular}

a percentage of germinated seeds; ${ }^{\mathrm{b}} \mathrm{cm}$; Control, untreated beans; $\mathrm{CH}$, chitosan-coated beans; $\mathrm{CH}-\mathrm{EO} 25 \%$, beans coated with chitosan added with $25 \%$ EO. Data are expressed as means \pm standard error.

The germination tests performed in the present study showed that the $\mathrm{CH}$ and $\mathrm{CH}-\mathrm{EO}$ coatings did not affect the germination and plantlet growth of the beans. This result is in contrast with the allelopathic effect shown by some EOs and their main components in several trials, although only observed in vitro [41,42]. In the soil, the allelopathic effect of EOs may be contrasted by dilution, absorption by the soil particles, and degradation (i.e., isomerization, oxidation, dehydrogenation, polymerization) of the EO chemical compounds [43]. The absence of phytotoxic effects observed in our trial may be due not only to the EOs chemical composition and intrinsic seed susceptibility but also to a residual lower EOs concentration. Actually, the use of EOs as active components of the seed coating allows their protective effect during the bean storage to be maximized, while minimizing the amount dispersed in the soil during the sowing phase and, consequently, their phytotoxic effects. 


\section{Conclusions}

Overall, this study showed that $F$. campestris EO, depending on the formulation (in solution or as active ingredient in the seed coating), is effective in suppressing the germination of weed seeds in vitro, without affecting the bean seeds (in vitro, up to a maximum tested EO concentration of $2.0 \mu \mathrm{g} / \mathrm{mL}$ ). It could, thus, represent a valid tool for sustainable agriculture alternatives both to synthetic herbicides for the control of weeds and to the synthetic insect-repellent and insecticidal agents for the control of seed pests. The growing concerns about synthetic chemicals and the consequent increasing demand for effective and safe natural products make EO-based products well accepted by consumers. Even if the variability of effectiveness of EOs has been considered a main drawback of their use in practice, in this research we observed a certain similarity of the EOs extracted from the same species collected in different geographical contexts, suggesting the possibility of using EOs with constant chemical characteristics and biological performances. Further research is, however, needed to evaluate the efficacy of selected EOs in real-life environments, such as in fields and storage facilities, as well as to evaluate the economic feasibility of the use of EOs in comparison with conventional products.

Author Contributions: Conceptualization, R.A., B.C. and D.F; formal analysis, S.B.; investigation, R.A., G.F., C.T., P.G., T.L., B.C. and D.F.; writing-original draft, R.A. and S.B.; writing-review and editing, R.A., G.F., S.B., C.T., B.C. and D.F. All authors have read and agreed to the published version of the manuscript.

Funding: This research was financed by the PRIMA program, project FEDKITO. The PRIMA program is supported by the European Union and by the Italian Ministero dell'Università e della Ricerca (MUR).

Institutional Review Board Statement: Not applicable.

Informed Consent Statement: Not applicable.

Data Availability Statement: Data are available on request.

Conflicts of Interest: The authors declare no conflict of interest.

\section{References}

1. The Plant List Ferulago campestris (Besser) Grecescu. The Plant List. Available online: http://www.theplantlist.org/tpl1.1/record/ kew-2808738 (accessed on 1 April 2020).

2. Cannon, J. Flora Europaea; Cambridge University Press: Cambridge, UK, 1993.

3. Maggi, F.; Tirillini, B.; Papa, F.; Sagratini, G.; Vittori, S.; Cresci, A.; Comam, M.M.; Cecchini, C. Chemical composition and antimicrobial activity of the essential oil of Ferulago campestris (Besser) Grecescu growing in central Italy. Flavour. Frag. J. 2009, 24, 309-315. [CrossRef]

4. Cecchini, C.; Coman, M.M.; Cresci, A.; Tirillini, B.; Cristalli, G.; Papa, F.; Sagratini, G.; Vittori, S.; Maggi, F. Essential oil from fruits and roots of Ferulago campestris (Besser) Grecescu (Apiaceae): Composition and antioxidant and anti-Candida activity. Flavour Frag. J. 2010, 25, 493-502. [CrossRef]

5. Riela, S.; Bruno, M.; Rosselli, S.; Saladino, M.L.; Caponetti, E.; Formisano, C.; Senatore, F. A study on the essential oil of Ferulago campestris: How much does extraction method influence the oil composition? J. Sep. Sci. 2011, 34, 483-492. [CrossRef]

6. Sabbieti, M.G.; Agas, D.; Maggi, F.; Vittori, S.; Marchetti, L. Molecular mediators involved in Ferulago campestris essential oil effects on osteoblast metabolism. J. Cell Biochem. 2011, 112, 3742-3754. [CrossRef]

7. Li, W.; Papa, F.; Shi, J.; Maggi, F.; Chen, X. The Chemical Constituents and the Hepato-protective Effect of the Essential Oil of Ferulago campestris (Besser) Grecescu (Apiaceae). J. Essent. 2016, 19, 1701-1708.

8. Conti, B.; Canale, A.; Bertoli, A.; Gozzini, F.; Pistelli, L. Essential oil composition and larvicidal activity of six Mediterranean aromatic plants against the mosquito Aedes albopictus (Diptera: Culicidae). Parasitol. Res. 2010, 107, 1455-1461. [CrossRef] [PubMed]

9. Bedini, S.; Bougherra, H.H.; Flamini, G.; Cosci, F.; Belhamel, K.; Ascrizzi, R.; Conti, B. Repellency of anethole-and estragole-type fennel essential oils against stored grain pests: The different twins. Bull. Insectol. 2016, 69, 149-157.

10. Ghasemi, V.; Moharramipour, S.; Tahmasbi, G. Biological activity of some plant essential oils against Varroa destructor (Acari: Varroidae), an ectoparasitic mite of Apis mellifera (Hymenoptera: Apidae). Exp. Appl. Acarol. 2011, 55, 147-154. [CrossRef]

11. Muturi, E.J.; Ramirez, J.L.; Doll, K.M.; Bowman, M.J. Combined toxicity of three essential oils against Aedes aegypti (Diptera: Culicidae) larvae. J. Med. Entomol. 2017, 54, 1684-1691. [CrossRef] [PubMed] 
12. Yeom, H.J.; Kang, J.S.; Kim, G.H.; Park, I.K. Insecticidal and Acetylcholine Esterase Inhibition Activity of Apiaceae Plant Essential Oils and Their Constituents against Adults of German Cockroach (Blattella germanica). J. Agric. Food Chem. 2012, 60, 7194-7203. [CrossRef]

13. Traboulsi, A.F.; El-Haj, S.; Tueni, M.; Taoubi, K.; Nader, N.A.; Mrad, A. Repellency and toxicity of aromatic plant extracts against the mosquito Culex pipiens molestus (Diptera: Culicidae). Pest Manag. Sci. 2005, 61, 597-604. [CrossRef] [PubMed]

14. Paul, U.V.; Lossini, J.S.; Edwards, P.J.; Hilbeck, A. Effectiveness of products from four locally grown plants for the management of Acanthoscelides obtectus (Say) and Zabrotes subfasciatus (Boheman) (both Coleoptera: Bruchidae) in stored beans under laboratory and farm conditions in Northern Tanzania. J. Stored Prod.Res. 2009, 45, 97-107. [CrossRef]

15. Baier, A.H.; Webster, B.D. Control of Acanthoscelides obtectus Say (Coleoptera: Bruchidae) in Phaseolus vulgaris L. seed stored on small farms-II. Germination and cooking time. J. Stored Prod. Res. 1992, 28, 295-299. [CrossRef]

16. Mallqui, K.S.V.; Oliveira, E.E.; Guedes, R.N.C. Competition between the bean weevils Acanthoscelides obtectus and Zabrotes subfasciatus in common beans. J. Stored Prod. Res. 2013, 55, 32-35. [CrossRef]

17. Gołębiowski, M.; Maliński, E.; Nawrot, J.; Stepnowski, P. Identification and characterization of surface lipid components of the dried-bean beetle Acanthoscelides obtectus (Say) (Coleoptera: Bruchidae). J. Stored Prod. Res. 2008, 44, 386-388. [CrossRef]

18. Oliveira, M.R.D.; Bonome, L.T.D.S.; Bittencourt, H.V.H.; Zarowni, E.; Lefchak, L.D.S. Alternative treatments in bean seeds for repelling Acanthoscelides obtectus (SAY). Res. J. Seed Sci. 2018, 40, 362-369. [CrossRef]

19. Girolami, V.; Mazzon, L.; Squartini, A.; Mori, N.; Marzaro, M.; Di Bernardo, A.; Greatti, M.; Giorio, C.; Tapparo, A. Translocation of neonicotinoid insecticides from coated seeds to seedling guttation drops: A novel way of intoxication for bees. J. Econ. Entomol. 2009, 102, 1808-1815. [CrossRef]

20. Badawy, M.E.; El-Aswad, A.F. Insecticidal activity of chitosans of different molecular weights and chitosan-metal complexes against cotton leafworm Spodoptera littoralis and oleander aphid Aphis nerii. Plant Protect Sci. 2012, 48, 131-141. [CrossRef]

21. Satyal, P.; Paudel, P.; Poudel, A.; Dosoky, N.S.; Moriarity, D.M.; Vogler, B.; Setzer, W.N. Chemical compositions, phytotoxicity, and biological activities of Acorus calamus essential oils from Nepal. Nat. Prod. Commun. 2013, 8, 8. [CrossRef]

22. Ricci, D.; Epifano, F.; Fraternale, D. The essential oil of Monarda didyma L.(Lamiaceae) exerts phytotoxic activity in vitro against various weed seed. Molecules 2017, 22, 222. [CrossRef] [PubMed]

23. Matoušková, M.; Jurová, J.; Grul'ová, D.; Wajs-Bonikowska, A.; Renčo, M.; Sedlák, V.; Poracovà, J.; Gogal'ová, Z.; Kalemba, D. Phytotoxic effect of invasive Heracleum mantegazzianum essential oil on dicot and monocot species. Molecules 2019, $24,425$. [CrossRef]

24. Mutlu, S.; Atici, Ö.; Esim, N.; Mete, E. Essential oils of catmint (Nepeta meyeri Benth.) induce oxidative stress in early seedlings of various weed species. Acta Physiol. Plant 2011, 33, 943-951. [CrossRef]

25. Ogunwande, I.A.; Avoseh, O.N.; Olasunkanmi, K.N.; Lawal, O.A.; Ascrizzi, R.; Flamini, G. Chemical composition, anti-nociceptive and anti-inflammatory activities of essential oil of Bougainvillea glabra. J. Ethnopharmacol. 2019, 232, 188-192. [CrossRef]

26. Adams, R.P. Identification of Essential Oil Components by Gas Chromatography/Mass Spectrometry; Allured Publishing Corporation: Carol Stream, IL, USA, 2007; p. 456.

27. Romani, R.; Bedini, S.; Salerno, G.; Ascrizzi, R.; Flamini, G.; Echeverria, M.C.; Farina, P.; Conti, B. Andean flora as a source of new repellents against insect pests: Behavioral, morphological and electrophysiological studies on Sitophilus zeamais (coleoptera: Curculionidae). Insects 2019, 10, 171. [CrossRef]

28. Peng, Y.; Li, Y. Combined effects of two kinds of essential oils on physical, mechanical and structural properties of chitosan films. Food Hydrocoll. 2014, 36, 287-293. [CrossRef]

29. Nahdy, M.S. Bean sieving, a possible control measure for the dried bean beetles, Acanthoscelides obtectus (Say) (Coleoptera: Bruchidae). J. Stored Prod. Res. 1994, 30, 65-69. [CrossRef]

30. Lombardi, T.; Bedini, S.; Bertacchi, A. Germination ecology of the aromatic halophyte Artemisia caerulescens L.: Influence of abiotic factors and seed after-ripening time. Folia Geobot. 2019, 54, 115-124. [CrossRef]

31. Hsiung, Y.C.; Chen, Y.A.; Chen, S.Y.; Chi, W.C.; Lee, R.H.; Chiang, T.Y.; Huang, H.J. Volatilized myrcene inhibits growth and activates defense responses in rice roots. Acta Physiol. Plant 2013, 35, 2475-2482. [CrossRef]

32. Scrivanti, L.R.; Zunino, M.P.; Zygadlo, J.A. Tagetes minuta and Schinus areira essential oils as allelopathic agents. Biochem. Syst. Ecol. 2003, 31, 563-572. [CrossRef]

33. Singh, H.P.; Batish, D.R.; Kaur, S.; Arora, K.; Kohli, R.K. $\alpha$-Pinene inhibits growth and induces oxidative stress in roots. Ann. Bot. 2006, 98, 1261-1269. [CrossRef]

34. Chowhan, N.; Singh, H.P.; Batish, D.R.; Kohli, R.K. Phytotoxic effects of $\beta$-pinene on early growth and associated biochemical changes in rice. Acta Physiol. Plant. 2011, 33, 2369-2376. [CrossRef]

35. De Feo, V.; De Simone, F.; Senatore, F. Potential allelochemicals from the essential oil of Ruta graveolens. Phytochemistry 2002, 61, 573-578. [CrossRef]

36. Martino, L.D.; Mancini, E.; Almeida, L.F.R.D.; Feo, V.D. The antigerminative activity of twenty-seven monoterpenes. Molecules 2010, 15, 6630-6637. [CrossRef] [PubMed]

37. Amri, I.; Gargouri, S.; Hamrouni, L.; Hanana, M.; Fezzani, T.; Jamoussi, B. Chemical composition, phytotoxic and antifungal activities of Pinus pinea essential oil. J. Pest. Sci. 2012, 85, 199-207. [CrossRef]

38. Papachristos, D.P.; Stamopoulos, D.C. Repellent, toxic and reproduction inhibitory effects of essential oil vapours on Acanthoscelides obtectus (Say) (Coleoptera: Bruchidae). J. Stored Prod. Res. 2002, 38, 117-128. [CrossRef] 
39. Jumbo, L.O.V.; Faroni, L.R.; Oliveira, E.E.; Pimentel, M.A.; Silva, G.N. Potential use of clove and cinnamon essential oils to control the bean weevil, Acanthoscelides obtectus Say, in small storage units. Ind. Crops Prod. 2014, 56, 27-34. [CrossRef]

40. Chaudhari, A.K.; Singh, V.K.; Kedia, A.; Das, S.; Dubey, N.K. Essential oils and their bioactive compounds as eco-friendly novel green pesticides for management of storage insect pests: Prospects and retrospects. Environ. Sci. Pollut. Res. 2021, 28, 18918-18940. [CrossRef]

41. Angelini, L.G.; Carpanese, G.; Cioni, P.L.; Morelli, I.; Macchia, M.; Flamini, G. Essential oils from Mediterranean Lamiaceae as weed germination inhibitors. J. Agric. Food Chem. 2003, 51, 6158-6164. [CrossRef] [PubMed]

42. De Almeida, L.F.R.; Frei, F.; Mancini, E.; De Martino, L.; De Feo, V. Phytotoxic activities of Mediterranean essential oils. Molecules 2010, 15, 4309-4323. [CrossRef]

43. Turek, C.; Stintzing, F.C. Stability of essential oils: A review. Compr. Rev. Food Sci. Food Saf. 2013, 12, 40-53. [CrossRef] 